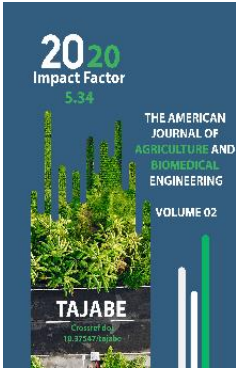

\title{
Expansion Of Irrigation Networks Is A Priority For The Agricultural Sector (On The Example Of Fergana Region)
}

\author{
Umidakhon Maripjanovna Akhmedova \\ Teacher at the department of Humanities of Andizhan Institute of Agriculture and \\ Agrotechnology, Andizhan region, Republic of Uzbekistan
}

\section{ABSTRACT}

The article analyzes the current archive materials and scientific literature that the expansion of irrigation networks in Ferghana region is a priority for the agricultural sector.

\section{KEYWORDS}

Irrigation, Ferghana region, agrarian sector, economy, reforms, modernization, Action strategy.

\section{INTRODUCTION}

After gaining independence, the Republic of Uzbekistan has set itself the ultimate goal of building a strong democratic state governed by the rule of law and a civil society based on a market economy and an open foreign policy. The ongoing reforms in Uzbekistan are aimed at improving the living standards of the population, reducing poverty and creating a prosperous life for the people. The role of the agricultural sector is enormous. As a result of the expansion of irrigation networks, the work on timely supply of water to farmers is yielding positive results. The unprecedented expansion of irrigation networks, accompanied by a high degree of mechanization of agricultural work and the use of advanced agricultural 
techniques, serves to increase the productivity of farmers.

\section{METHODS}

Improving the reclamation of irrigated lands, development of land reclamation and irrigation facilities, intensive gardening, water and resource-saving, introduction of modern agrotechnologies, use of high-efficiency techniques [1].

\section{RESULTS AND DISCUSSIONS}

On September 1-7, 2019, the III World Irrigation Forum and the 70th International Executive Board meeting of the International Commission on Irrigation and Drainage were held in Bali, Indonesia. Uzbekistan became a member of the organization in 1993, and in 2006 the National Committee for Irrigation and Drainage of the Republic of Uzbekistan was established. At the 7oth meeting of the International Executive Council of the International Commission on Irrigation and Drainage, large-scale reforms in the rational use of water resources in our country, prospects for bilateral and multilateral cooperation with countries in the region on water efficiency, measures to introduce watersaving technologies, Aral the impact of the tragedy on the ecological environment of the region and the world. Members of the Executive Council and participants of the meeting praised the work done by the Government of Uzbekistan in the field of rational use of water resources, irrigation and drainage.

Resolution of the First President of the Republic of Uzbekistan dated April 19, 2013 “On measures to improve the reclamation of irrigated lands and further improve the rational use of water resources for 2013-2017", the
Cabinet of Ministers of June 21, 2013 Resolution of August 29, 2015 "On measures for the effective organization of the introduction and financing”, Resolution of August 29, 2015 “On a comprehensive program of measures for the rehabilitation and socio-economic development of the Aral Sea region, mitigation of the consequences of the Aral Sea disaster" and others including [3].

In our country, in this regard, in the Fergana region, effective work is being done on irrigation. Several pumping stations in the region have been reconstructed and new ones put into operation.

Beshariq pumping station of Besharik district was reconstructed and put into operation in 2015 by China IPPR international Enginering in 2011-2015 at the expense of the Asian Development Bank on the basis of the Decree of the President of the Republic of Uzbekistan PD-704 dated October 9, 2007. During the reconstruction, new high-efficiency, energyefficient pumping units, power equipment and other hydraulic equipment were installed. The buildings have been overhauled, $18.5 \mathrm{mln}$. dollars were spent. Dangara pumping station of Dangara district was reconstructed and commissioned in 2016 by China IPPR International Engineering in 2013-2016 at the expense of loans from the Asian Development Bank in accordance with the Decree of the President of the Republic of Uzbekistan dated August 10, 2009 No PP-1172. During the reconstruction, a new water supply canal was built. New high-efficiency, energy-efficient pumping units, power equipment and other hydraulic equipment have been installed in the open field. The buildings have been overhauled. $12.1 \mathrm{mln}$. dollars were spent.

The "Furkat-1" pumping station in Furkat district was reconstructed by the Japanese company CUBBOTA in 2013-2016 at the 
The American Journal of Agriculture and Boimedical Engineering (ISSN - 2689-1018)

Published: October 28, 2020 | Pages: 17-22

Doi: https://doi.org/10.37547/tajabe/Volume02Issue10-04

expense of a loan from the Asian Development Bank in accordance with the Decree of the President of the Republic of Uzbekistan dated August 10, 2009 No PD-1172 and commissioned in 2016. During the reconstruction, new highefficiency, energy-efficient pumping units, power equipment and other hydraulic equipment were installed. The buildings have been overhauled. 11.5 million for these works. dollars were spent.

The pumping station "Sharqiy Arsif" of Kuva district was reconstructed at the expense of the State budget on the basis of the Decree of the President of the Republic of Uzbekistan dated April 13, 2013 No PP-1958. During the reconstruction, 7 pumping units of the new $D$ 1250/125 brand were installed instead of the old 10 NMK pumping units. Power equipment and other equipment were upgraded and the buildings were repaired. $5400.0 \mathrm{mln}$. soums were spent.

Pump station "Kuva-1" of Kuva district was reconstructed at the expense of the State budget on the basis of the Decree of the President of the Republic of Uzbekistan dated April 13, 2013 No PD-1958. During the reconstruction, pump units TsN 3000-197 were repaired and installed. Power equipment and other equipment were upgraded and the buildings were repaired and $6400.0 \mathrm{mln}$. soums were spent.

Baghdad pumping station of Kuva district was reconstructed at the expense of the state budget on the basis of the Decree of the President of the Republic of Uzbekistan dated April 13, 2013 No PD-1958. During the reconstruction, 9 pump units of the new TsN $1000 / 180$ brand were installed instead of the old 10 NMK pump units. Power equipment and other equipment were upgraded and the buildings were repaired. In addition to the reconstructed pumping stations, the following new pumping stations were commissioned.

Ziyo pumping station of Yazyovan district was implemented under the project "Construction of Ziyo pumping station to improve the water supply of farms in Yazyovan district", approved by the Decree of the President of the Republic of Uzbekistan dated December 29, 2010 No PD1455. The pumping station was newly built at the expense of the Capital Construction Fund of the Ministry of Agriculture and Water Resources. The construction work was carried out by FE "Ferghanaumumtadbirkurloyiha". The total cost of the project is $359.305 \mathrm{mln}$. soums. Construction and installation work began in March 2016 and was completed in December 2016.

Aral pumping station of Dangara district was implemented under the project "Construction of Aral pumping station to improve the water supply of farms in Dangara district", approved by the Decree of the President of the Republic of Uzbekistan dated December 29, 2010 No PD1455. The pumping station was newly built at the expense of the Capital Construction Fund of the Ministry of Agriculture and Water Resources. The construction work was carried out by FE "Ferghanaumumtadbirkurloyiha". The total cost of the project is $\mathbf{5 1 7 . 0 7 1}$ million soums. Construction and installation work began in April 2016 and was completed in December 2016.

Pumping station "Ok-Oltin" of Furkat district was implemented under the project "Construction of a pumping station Ok-Oltin" to improve the water supply of farms in Furkat district, approved by the Decree of the President of the Republic of Uzbekistan dated December 29, 2010 No PD-1455. The pumping station was newly built at the expense of the Capital Construction Fund of the Ministry of Agriculture and Water Resources. The 
construction work was carried out by FE "Ferghanaumumtadbirkurloyiha". The total cost of the project is $335.160 \mathrm{mln}$. soums. Construction and installation work began in 2016 and was completed in December 2016.

Pumping station "Dormon MNS" of Kushtepa district was implemented under the project "Construction of a pumping station" Dormon MNS to improve the water supply of farms in Kushtepa district, approved by the Decree of the President of the Republic of Uzbekistan dated December 29, 2010 No PD-1455. The pumping station was newly built at the expense of the Capital Construction Fund of the Ministry of Agriculture and Water Resources. The construction work was carried out by FE "Ferghanaumumtadbirkurloyiha". The total cost of the project is \$ 349.454 million. soums. Construction and installation work began in 2016 and was completed in December 2016.

The Ipak Yuli pumping station in Dangara district was built under the project "Construction of the Ipak Yuli pumping station to improve water supply to farms in Dangara district" approved by the Decree of the President of the Republic of Uzbekistan dated January 13, 2016 No.-3-AF. The pumping station was newly built at the expense of the Capital Construction Fund of the Ministry of Agriculture and Water Resources. The construction work was carried out by Ferganaumtadbirkurloyiha. The total cost of the project is $1,075.060$ million soums. soums. Construction and installation work began in 2016 and was completed in December 2016.

The Choligulistan pumping station in Baghdad district was built under the project "Construction of the Chuligulistan pumping station to improve the water supply of farms in Baghdad district," approved by the President of the Republic of Uzbekistan on December 29,
2010 No PD-1455. The pumping station was newly built at the expense of the Capital Construction Fund of the Ministry of Agriculture and Water Resources. The construction work was carried out by FE "Ferghanaumumtadbirkurloyiha". The total cost of the project is 356.649 million soums. Construction and installation work began in 2016 and was completed in December 2016.

Pumping station "Dehkontuda" in Besharik district was implemented under the project "Construction of Chuliguliston pumping station to improve the water supply of farms in Baghdad district" approved by the President of the Republic of Uzbekistan on December 29, 2010 No PD-1455. The pumping station was newly built at the expense of the Capital Construction Fund of the Ministry of Agriculture and Water Resources. The construction work was carried out by FE "Ferghanaumumtadbirkurloyiha". The total cost of the project is $\$ 286.504$ million. soums. Construction and installation work began in 2016 and was completed in December 2016.

Achchikkul pumping station of Buvayda district was implemented under the project "Construction of Achchikkul pumping station to improve the water supply of farms in Buvayda district" approved by the President of the Republic of Uzbekistan on November 21, 2012 No PD-1855. The pumping station was newly built at the expense of the Capital Construction Fund of the Ministry of Agriculture and Water Resources. The construction work was carried out by FE "Ferghanaumumtadbirkurloyiha". The total cost of the project is $\$ 286.504$ million. soums. Construction and installation work began in 2016 and was completed in December 2016.

Farovon pumping station of Baghdad district is implemented under the project "Construction of Achchikkul pumping station to improve the 
water supply of farms in Buvayda district," approved by the President of the Republic of Uzbekistan on November 21, 2012 No PD-1855. The pumping station was newly built at the expense of the Capital Construction Fund of the Ministry of Agriculture and Water Resources. The construction work was carried out by FE "Ferghanaumumtadbirkurloyiha". The total cost of the project is 470.865 million soums. soums. Construction and installation work began in 2016 and was completed in December 2016.

Pumping station "Akjar (D-10)" of Dangara district was implemented under the project "Construction of pumping station Akjar (D-10) to improve the water supply of farms in Dangara district, approved by the Decree of the President of the Republic of Uzbekistan dated November 21, 2012 No PK-1855" . The pumping station was newly built at the expense of the Capital Construction Fund of the Ministry of Agriculture and Water Resources. The construction work was carried out by FE "Ferghanaumumtadbirkurloyiha". The total cost of the project is \$286.504 million. soums. Construction and installation work began in 2016 and was completed in December 2016.

Sarikkamish pumping station of Besharik district was implemented under the project "Construction of Sarikkamish pumping station to improve the water supply of farms in Besharik district" approved by the Decree of the President of the Republic of Uzbekistan dated November 21, 2012 No PD-1855. The pumping station was newly built at the expense of the Capital Construction Fund of the Ministry of Agriculture and Water Resources. The construction work was carried out by FE "Ferghanaumumtadbirkurloyiha". The total cost of the project is $\mathbf{2 8 6 . 5 0 4}$ million soums. Construction and installation work began in 2016 and was completed in December 2016.

\section{CONCLUSION}

In Uzbekistan, on the initiative of President Shavkat Mirziyoyev, large-scale work on the efficient use of water resources, the effective use of available water resources and the widespread introduction of cost-effective irrigation technologies are important to ensure guaranteed yields of agricultural crops and food security emphasizes that. The widespread introduction of the irrigation system in our country, the use of facilities created by the state for this purpose will serve to develop agricultural production and further improve the welfare of our people.

\section{REFERENCES}

1. Scientific-methodical brochure on the study of the State Program for the implementation of the Action Strategy for the five priority areas of development of the Republic of Uzbekistan in 2017-2021 in the "Year of dialogue with the people and the interests of man".- Tashkent-2017. 130-p.

2. M.Turdiboeva Rational use of land and water resources: problems, history and results // Spiritual-educational and political maturity - a guarantee of social development.-T .: 2016. 165 pages.

3. From the 2010 report of the Syrdarya-Sogd Irrigation Systems Department.

4. From the 2012 report of the Syrdarya-Sogd Irrigation Systems Department.

5. From the 2013 report of the Syrdarya-Sogd Irrigation Systems Department. 
The American Journal of Agriculture and Boimedical Engineering (ISSN - 2689-1018)

Published: October 28, 2020 | Pages: 17-22

Doi: https://doi.org/10.37547/tajabe/Volume02Issue10-04

6. From the 2016 report of the Syrdarya-Sogd Irrigation Systems Department. 